\title{
DESIGN OF INDUSTRIAL BIOMETHANE DIGESTER ATTACHED WITH UPGRADING AND STORAGE UNITS
}

\author{
M. M. Badr
}

\section{ABSTRACT}

The recent rise in energy demand to support industrialization and civilization is resulting in increased stress on conventional energy sources. Faced with the accompanying problem of climate change, research in renewable energies, especially their commercialization, has never been more important. Biogas production is a major renewable energy source. The rabbit wastes could not be completely used in biogas production as a result of certain restrictions are related with it, prevalent among these are the increase hydraulic retention time, low both gas production and calorific value this could be essentially attributed to the lower biodegradability of this wastes. So, efforts are required to take off its constraint in order to spread this technology and fully commercialized.

This research focused on the design and construction of an integrated geometrical system to produce, purify, and store methane that can be implemented in commercial-size models in general and for rabbit farms especially. The results showed that the highest methane production recorded was $241.73 \mathrm{l} / \mathrm{kg}$ OTS for a three-time agitation rate of rabbit droppings. The methane concentration in the raw biogas was 57.5, 62.5 and 67.5\%. The calorific values of purified biogas reached a high of $33.35 \mathrm{~kJ} / \mathrm{l}$. The methane content increased by $37.39 \%$ after undergoing the upgrading process at a constant gas pressure of 8.53 mbar and a methane proportion in the raw biogas of about $67.5 \%$.

\section{INTRODUCTION}

$\mathrm{M}$ ethane is a promising option to confront growing energy requirements and is a clean and active fuel for several applications. However, the non-combustible components of $\mathrm{CO}_{2}, \mathrm{H}_{2} \mathrm{~S}$, and water vapor lead to a reduction in its calorific value, which has limited its use. Abundant research has been conducted for optimizing the biogas yield, although there has been a lack of information on biogas upgrading.

\footnotetext{
"Assistant professor of Agric. Eng., Fac. of Agric., Zagazig Univ. Egypt.
} 
Thus, biogas applications remain uneconomical. An equally significant aspect is the design of a biogas digester that is suitable and optimal for small farms. Therefore, a sample industrial biogas digester is presented in this paper. The three major objectives of this study are as follows: (i) design and establish an integrated geometrical system to optimize the biogas production potential from animal wastes as well as purify and store it; (ii) provide more information about the relationship between biogas production potential from local biomasses and its chemical composition under different agitation rates; and (iii) evaluate the purification process and its impact on biogas calorific value.

El-Bakhshwan et al. (2015) reported that the stirring intensity and duration are the main factors affecting the digester mixing strategy. Adequate mixing was shown to achieve better substrate and microorganism distributions throughout the digester, whereas inadequate mixing caused layers of floating solids. Intermediate mixing can be turned on and off according to a preset time interval and appeared to be optimal for digester performance and methane production coupled with mixing intensity. These findings concur with the results of Lemmer et al. (2013), who showed that stirring or not stirring results in significant differences in biogas production for different mixtures and plays an important role in biogas production quantity and quality. This conclusion was also reached by Kowalczyk et al. (2013), who confirmed that scum on the surface is a problem that can occur when the agitation process is neglected. Therefore, it can be concluded that mixing during the digestion process is an indispensable and manageable step.

Brunetti et al. (2015) reported that the presence of gases such as $\mathrm{CO}_{2}$ and $\mathrm{H}_{2} \mathrm{~S}$ strongly reduces the fuel calorific value and is corrosive, making compression and long-distance transport difficult. Consequently, Brunetti et al. (2015) and Bajracharya et al. (2009) reported that the substantial influence of the upgrading process (removal of incombustible and corrosive gases) to increase its energy and calorific value before compression, transportation, and storage; thus, its utilization by supplying it directly to natural gas pipelines is economically feasible. This conclusion is in agreement with that of Nallamothu et al. (2013), who reported that purifying the biogas via steel wool, water, and silica 
gel to reduce the presence of hydrogen sulfide, carbon dioxide, and water vapor, respectively, leads to an increase in methane concentration from $68 \pm 2.52 \%$ to $90 \pm 1.53 \%$. Similarly, Ray et al. (2016) and Gaikwad and Katti (2015) also confirmed this finding; they defined the importance of using limestone crystals, silica gel, and steel wool to remove $\mathrm{CO}_{2}$, water vapor, and hydrogen sulfide, respectively, in biogas purification because these impure gases decrease the heating capacity and become problematic when compressing and bottling the biogas. After multiple scrub units, the biogas purity can be increased from $95 \%$ to $98 \%$.

\section{MATERIALS AND METHOD}

This research offers an integrated technique that is designed for biogas production and upgrading in Rabbit Farms as a replacement for other traditional digesters, taking into consideration all of the parameters required for accessible of biogas production effectively. The experiments were conducted in a biogas laboratory at Faculty of Agriculture, Zagazig University, Egypt. In this study, it was suggested designing and constructing the integrated geometrical system for producing biogas with purify and storage units of methane gas, as shown in Figure 1. Designed digester provides a safe and cleaner way for storing rabbit waste and therefore getting about related advantages linked to reduce of health problems caused by this wastes inside rabbit farms. And therefore, getting cheap fuel for cooking, heating and lighting compared to the other fuels.

Industrial Biogas Digester (IBD) is vertical tank attached with gascollecting unit after the purification process of methane gas. where the influent of rabbit waste is added and removed from the reactor in continuously. This design is best suited of waste streams in rabbit farms.

There is little information on the optimum frequency of mixing in rabbit wastes fed digesters. but Preliminary tests was indicated the gas production increases dramatically when mixing is undertaken, slowly and many times per day, so different time intervals between mixes was executed to identify the optimum level. Mixing of the slurry can increase gas production by ensuring an even distribution of bacteria and fresh substrate. The agitator is fitted with motor-driven rotating paddles. 


\subsection{Animal wastes}

To prepare the slurry of raw material (rabbit droppings) was collected from the research and experimental farm of the Faculty of Agriculture, Zagazig University. The collected raw material was analyzed for organic matter, crude protein, crude lipid, carbohydrate, and lignin contents. The dry matter content was measured after a 24-hour drying period at $105^{\circ} \mathrm{C}$, while the organic matter content was determined based on the ash content following incineration at $550^{\circ} \mathrm{C}$ for three hours.

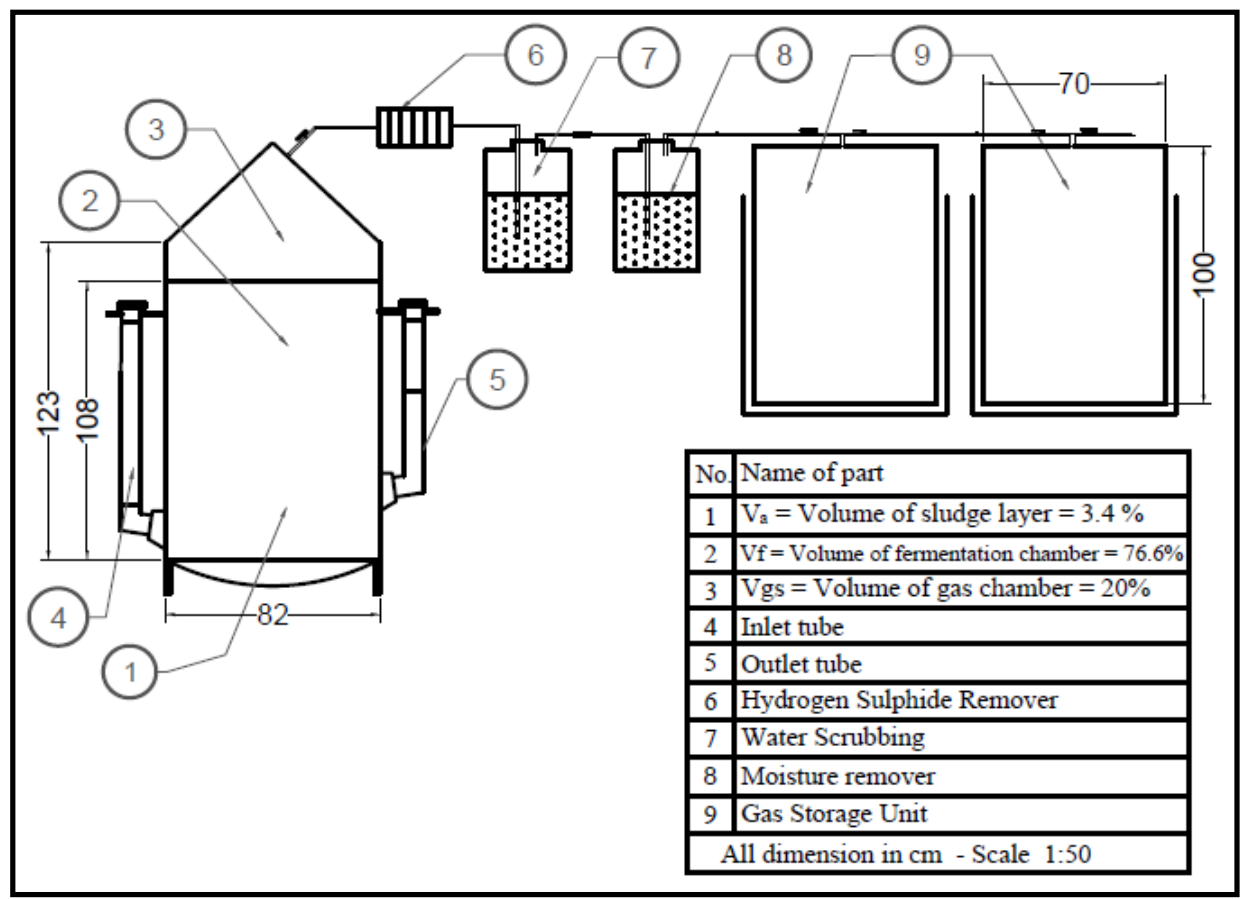

Fig. 1: Integrated geometrical system for producing bio-methane.

The total protein content was determined according to the standard method (AOAC, 2000). The $\mathrm{pH}$ was measured using a Jenway 3020 digital $\mathrm{pH}$ meter. Carbon and nitrogen concentrations (\%) were determined before digestion using the Walkley-Black and the Kjiedhal as standard methods. $\mathrm{pH}$ values (ranging between 7.0 and 7.8) were suitable for anaerobic digestion. The theoretical biochemical methane potential (BMP) was calculated using the organic composition. Bushwell's formula indicates the amount of methane provided by the different compounds, According to Lesteur et al., 2010 as shown in the following equation: 
$\mathbf{B M P}=415 \times$ carbohydrates $\%+496 \times$ proteins $\%+1014 \times$ lipids $\%$.

All values obtained from the analysis were deemed appropriate for microorganism activity as it relates to anaerobic digestion. Water was added to raw materials to form slurries with a desired total solid concentration of 7.9-10\%. Rabbit dung and water were manually homogenized before setting them into the digesters. The digester was filled at the beginning with starter (inoculum). The fermentation temperature was $38^{\circ} \mathrm{C}$ (mesophilic).

The inflow volume of biogas was collected in a gas holder and measured by the displacement of water and a previously calibrated scale in liters. The percentage of methane in the produced biogas was analyzed by injecting the biogas sample into a test tube with $40 \%$ potassium hydroxide $(\mathrm{KOH})$ to remove $\mathrm{CO}_{2}$. The methane and carbon dioxide concentrations were determined by comparing the inlet and outlet volumes of biogas according to Okeke and Ezekoye (2006).

Instability during both start-up and operation of the process can be problematic due to the low specific growth rate of the methanogenic microorganisms, as found by Bjornsson et al. (1997). However, producing $\mathrm{CH}_{4}$ can be supported by improving the cultures of methanogenic microorganisms via a starter (inoculum). For this reason, in this study, a starter from a reactor broth running with cattle dung was fed in before the influent slurry exited the fermentation chamber to create a mixture, improving both the microbial activity and anaerobic biodegradability.

The experiment was performed in the same digester four times under different agitation rates to evaluate the digester performance. Moreover, was working under similar conditions from the beginning until the end of the experiments. Mechanical agitation occurred for 20 minutes one, two, three, and four times daily.

\subsection{Design of integrated geometrical system}

This study aims many of the technical aspects for designing and constructing an industrial bio-digester with supplied to gas-purifying unit to produce biomethane from rabbit waste. The design aspects included calculations of both the total volume, working volume and gas storage unit for industrial reactor as well as biogas upgrading unit and energy content. 


\subsubsection{Industrial digester design:}

The total volume of the digester broadly depends on the amount of wastes to be added during digestion process. Digester dimensions should enable a surface area for volume ratio to be achieved to the maximum of both gas daily with energy content and in addition to provide the suitable operating conditions, at this point it is worth mentioning to note that some the design details will be determined through practice and empirical data. With regard to calculate the required total volume and the provider with a storage unit on conical form often work best in this design as follows:

$$
\mathrm{V}_{\mathrm{t}}=\mathrm{V}_{\mathrm{w}}+\mathrm{V}_{\mathrm{s}}
$$

Where: $V_{t}$ is the total volume of digester, $V_{w}$ is working volume and $V_{s}$ is gas holder volume. The ratio of the total volume to the gas holder volume is a main factor when designing a digester. As to a standard biogas plant this rate ranges being $(5: 1-6: 1) \mathrm{V}_{\mathrm{s}}=0.20 \mathrm{~V}_{\mathrm{t}}$ and therefore $\mathrm{V}_{\mathrm{w}}=0.80 \mathrm{~V}_{\mathrm{t}}$.

$$
\mathrm{V}_{\mathrm{w}}=\mathrm{V}_{\mathrm{i}} \times \mathrm{HRT}
$$

Where: $V_{i}$ is volume of influent required and HRT is hydraulic retention time.

$$
\mathrm{V}_{\mathrm{i}}=\frac{\mathrm{W}_{\mathrm{i}}}{v_{w}}
$$

Where: $\mathrm{W}_{\mathrm{i}}$ is influent weight and $v_{\mathrm{w}}$ and is specific weight of rabbit droppings. With respect to calculate weight of total solid from rabbit droppings was used the following equation and CR has been chosen by $8 \%$.

$$
\mathrm{W}_{\mathrm{i}}=\mathrm{W}_{\mathrm{TS}} \times \mathrm{CR}
$$

Where: $\mathrm{W}_{\mathrm{TS}}$ is weight of total solid and CR is concentration ratio.

$$
\mathrm{W}_{\mathrm{TS}}=\mathrm{W}_{\mathrm{w}} \times \mathrm{TS}
$$

Where: $\mathrm{W}_{\mathrm{w}}$ is weight of droppings discharge and TS is total solid ratio. Therefore, the following equation should be used to calculate volume of fermentation chamber in the case of setting volume of activated sludge by $4.25 \%$ from working volume of digester.

$$
\mathrm{V}_{\mathrm{w}}=\mathrm{V}_{\mathrm{f}}+\mathrm{V}_{\mathrm{a}}
$$

Where: $V_{f}$ is volume of fermentation chamber and $V_{a}$ is volume of activated sludge. The final design in this part is diameter of the digester, $\mathrm{cm}$ which was calculated as relationship with the total volume, litter as follows:

$$
\mathrm{D}=0.905 \times \mathrm{V}_{\mathrm{t}}^{\frac{1}{3}}
$$




\subsubsection{Construction of biogas upgrading technique}

The biogas upgrading and storage technique was designed to raise energy content and obtainment biomethane from wastes. The upgrading system was based on chemical absorption methods and consists of three units: carbon dioxide, the hydrogen sulfide, and moisture elimination units. Upgrading experiment was conducted by passing raw biogas with low pressure into the oxidized steel wool unit to remove hydrogen sulfide. Then, the gas was entered into water scrubbing unit of carbon dioxide dissolve, which formed carbonic acid $\left(\mathrm{H}_{2} \mathrm{CO}_{3}\right)$ and to reach water contents as low as in the purified biogas; the silica gel crystal was used for absorbing moisture.

\subsubsection{Selection size of gas storage unit:}

The gas collection unit was designed to collect the methane produced after undergoing the upgrading units. The chosen system consisted of a onesided open cylindrical vessel overturned downward over another standing upward. The one-sided open cylindrical vessel upward was filled with a fluid. At the end of the inverted cylindrical vessel was attached a meter stalk for measuring methane productions. To calculate the theoretical volume of daily gas production $\mathrm{V}_{\text {th }}$ can be used one of the following equations, it is best using both of them and takes an average of volume value.

$$
\mathrm{V}_{\text {th }}=\mathrm{DGP} \times \mathrm{t}
$$

Where: DGP and t are daily gas production and consumption time.

The upgrading process has a noticeable improvement resultant biomethane concentration from produced biogas. To designate volume of methane gas collection unit, Vm should be used an extra $20 \%$ safety stock with is taken methane ratio into consideration.

$$
\mathrm{V}_{\mathrm{m}}=1.2 \times \mathrm{V}_{\mathrm{th}}
$$

\subsection{Energy content of the biogas}

The aim of the biogas upgrading technique in this study was to increase the energy obtained from biogas. In practice, this is performed by removing the majority of the carbon dioxide, hydrogen sulfide, and moisture. The calorific value of the biogas is a vital parameter for the performance of a burner or any other application using biogas as a fuel. The actual calorific value $(\mathrm{kJ} / \mathrm{l})$ of the produced biogas was calculated using the following equation, Klaus, 1988: 


$$
\mathrm{H}_{\mathrm{u}, \mathrm{act}}=\frac{V_{\mathrm{CH}_{4}}}{\mathrm{~V}_{\mathrm{t}}} \times \rho_{\mathrm{CH}_{4}} \times H_{u, n}
$$

Where $\mathrm{H}_{u}$, act is the actual calorific value of the produced biogas, $\mathrm{kJ} / \mathrm{l}$; $\mathrm{V}_{\mathrm{CH}} / \mathrm{V}_{\mathrm{t}}$ is the methane proportion in the biogas; $\rho_{\mathrm{CH} 4}$ is the biogas density, $\mathrm{kg} / \mathrm{m}^{3}$; and $\mathrm{H}_{\mathrm{u}, \mathrm{n}}$ is the calorific value of the biogas at standard conditions, $\mathrm{kJ} / \mathrm{kg}$ (assumed to be $50000 \mathrm{~kJ} / \mathrm{kg}$ or $36000 \mathrm{~kJ} / \mathrm{m}^{3}$ ).

\section{RESULTS AND DISCUSSION}

The results of this study is based on a design requirements and performance evaluation of integrated geometrical system for producing, upgrading and storing methane in rabbit farms to improve the yield of both from the daily volume of the biogas yield and the actual calorific value of producing biogas using purified gas in the varied applications. Consequently, it is necessary commence in the design results using the equations presented in material and methods and involves the following items:

\subsection{Size of industrial digester}

Digester size can be calculated according to determine working volume, volume of the gas holder and then assignment the total volume. Initially, it is identified total solid amount and weight of influent required that is added to the digester with concentration of $8 \%$ as follows $\mathrm{W}_{\mathrm{TS}}=1.74 \mathrm{~kg}$ and $\mathrm{W}_{\mathrm{i}}=$ $21.75 \mathrm{~kg}$. The previous quantity of rabbit droppings needs to be disposed of and treated with hydraulic retention time an average of 30 days. Working volume, $\mathrm{V}_{\mathrm{w}}=594.12 l$, the total volume of digester $\mathrm{V}_{\mathrm{t}}=742.65 l$ and volume of the gas holder is equivalent to $148.53 \mathrm{l}$. The final step in this part of the calculation is to determine the digester diameter $\mathrm{D}=82 \mathrm{~cm}$.

Volume of methane gas collection unit, $\mathrm{V}_{\mathrm{m}}=662.86 l$ and then collection unit was installed on two phases as shown in Figure 1. The gas volume has been corrected through temperature correction at constant pressure process after deducting the volume of gas holder and taking into an extra 20\% safety stock. Upgrading and store technique has been provided with the production unit for concentrating biomethane from produced biogas in order to improve the energy content in addition to reducing the size required for gas storage unit.

\subsection{Impact of stirring on biogas and methane production}

The stirring process has a very impact for a digestion reactor; it can be adjusted to achieve various objectives: (i) improve the connection between 
the particle organic substrate and micro organisms to increase degradation and the breakdown of biodegradability compounds and improve the production rate; (ii) standardize the temperature distribution; (iii) reduce the risk of scum formation and support gas movement from the fermentation area to the storage unit; (iv) isolate particles from sedimentation as well as form a homogenous mixture; and (v) retain the micro organisms in the reactor, as shown by Brehmer et al. 2012 and Lemmer et al. 2013.

The biogas yield and its methane content were recorded daily under different agitation rates. Fig. 2 shows the impact of disparate mixing ratios and different agitation rates on the biogas and methane production per [1/digester $]$ - $\left[1 / \mathrm{kg}_{\mathrm{oTS}}\right]$.

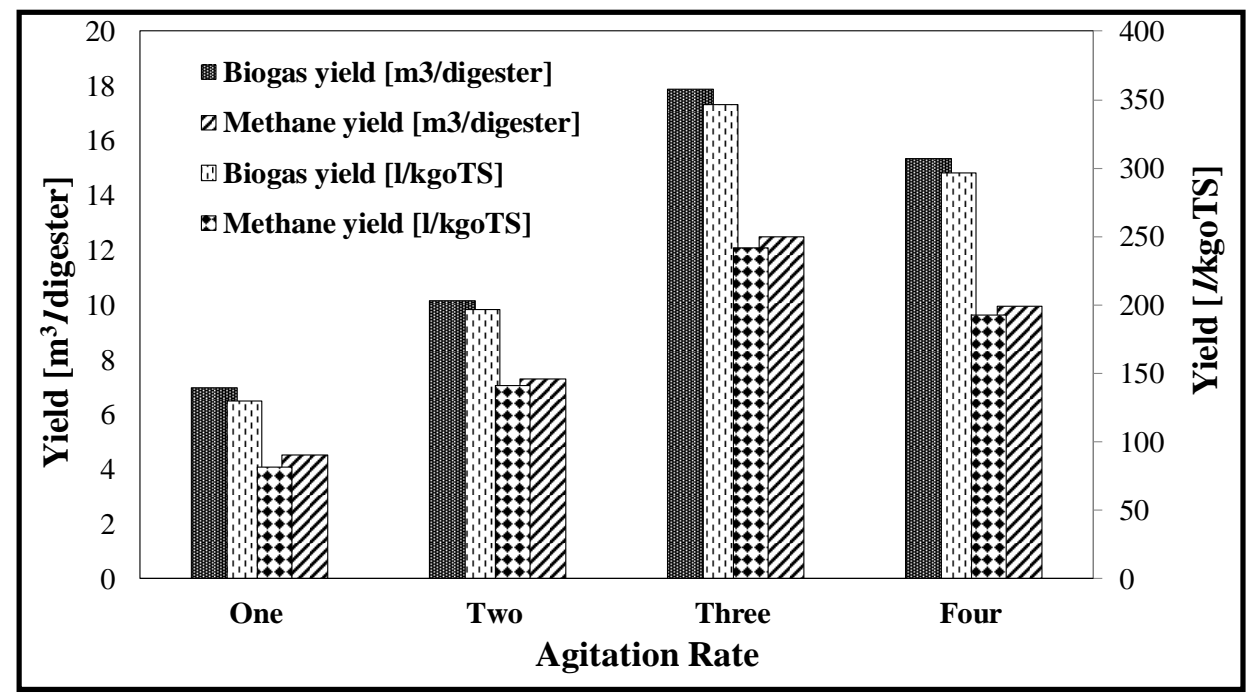

Fig. 2:Biogas and methane production under different agitation rates.

Results obtained show that increasing mixing times per day increased biogas production and methane yield up to three times, any further increase in mixing up to four times gas production will decrease. It was noticed that increasing mixing times from one to three times increased biogas production and methane yield from 6.95 to 17.89 and from 4.52 to $12.50 \mathrm{~m}^{3} /$ digester, respectively. Any further increase in mixing times up to four times led to decrease biogas production and methane yield by the rate of 14.31 and $20.32 \%$, consecutively. It was evident that the highest biogas production and methane yield were 346.02 and $241.72 \mathrm{l} / \mathrm{kg}_{\mathrm{oTS}}$ measured at three times 
mixing. While increasing mixing per day up to four times decreased biogas and methane yield by the value of 296.51 and $192.73 \mathrm{l} / \mathrm{kg}_{\mathrm{oTS}}$, respectively. From the obtained results show that the biogas production and methane yield increased when the stirring rate increased to three times per day, due to preventing solids from settling to the bottom of the digester bottom while simultaneously supporting the homogeneity and nutrient distribution requirements for the microorganism. However, when the agitation rate increased to four times per day for the purpose of improving the viscosity and homogeneity of the mixtures, the biogas production decreased attributed to negative impact on growth and activity for the microorganism.

Furthermore, continued stirring does not result in a perfect biogas yield, and stirring more than needed not only results in limited or no improvement in the performance of the reactor but also uses energy in mixing the reactor contents. There are also adverse effects on microorganism growth. This finding was also obtained by Karim et al. 2005, who explained that stirring does not have an impact when the solid concentration of the fed slurry decreases or the hydraulic retention time increases. Each of these results makes an important contribution to our understanding of mixing, and it becomes more substantial as the TS feed concentration increases.

\subsection{Impact of the stirring rate on the time needed for ultimate digestion}

The different agitation strategies showed the influence of the time needed for complete fermentation. However, there are limitations to microorganism activity with agitation because the effect of increased agitation on microorganism activity disturbances is more than that of the substrates. Moreover, bacterial activity is the success secret of the anaerobic digestion process. Fig. 3 illustrates the effect of applying different agitation rates daily methane production 1/digester and retention time at standard temperature and pressure (STP). A negative relationship between the stirring rate and retention time exists. All the experiments were terminated when the biogas yield nearly ceased. As shown in the figure above, the anaerobic digestion process required 30,21,18, and 16 days for agitation one, two, three, and four times per day, respectively. The results show that the biogas production in large-scale digesters can be optimized using mechanical agitation. More compelling evidence points to the effect of the animal waste type and stirring ratio on the biogas and methane yield, which can be demonstrated 
when the production from one $\mathrm{kg}$ of rabbit dung is compared under different agitation conditions.

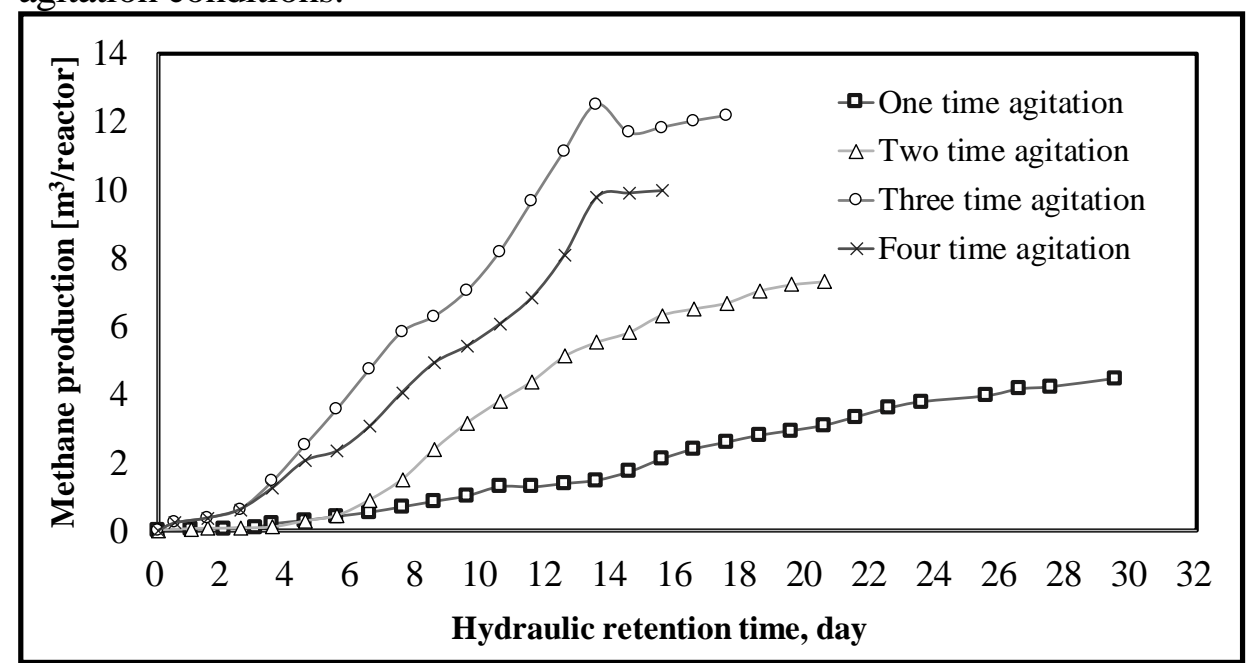

Fig. 3: Daily methane production under different agitation rates.

\subsection{Theoretical versus actual methane yield}

Figure 4 shows that the highest biodegradability efficiency in this study was 84.26\% for stirring three times per day, whereas the lowest efficiency (28.32\%) was obtained for stirring one time per day. However, the changes in the biodegradability efficiency under different agitation rates are similar to the behavior of methane production. The biodegradability efficiency was higher for three times per day compared with one, two or four times per day.

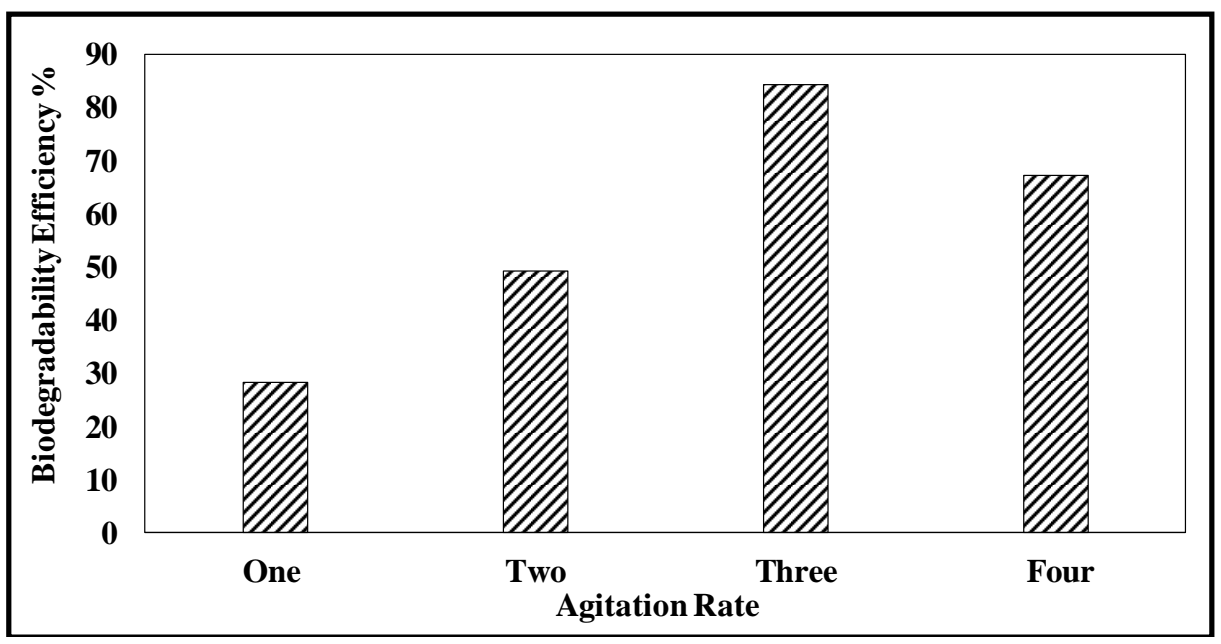

Fig. 4: Biodegradability efficiency under different agitation rates. 


\subsection{Impact of upgrading process on methane production}

The upgrading of the raw biogas was performed using different chemicals in varied applications. From the obtained results during a production experiment, the methane proportion available in the raw biogas was approximately $57.5 \%, 62.5 \%$, and $67.5 \%$. Representative values of both the methane proportion and calorific value of the purified biogas versus gas pressure at a different methane proportion of raw biogas are given in Figs. 5 and 6. The results of the upgrading process show that the methane proportion of the purified biogas varies with gas pressure. The methane proportion in the purified biogas increased by increasing the gas pressure up to 8.53 mbar; with a further increase in gas pressure to 10.88 mbar, the methane proportion decreased.

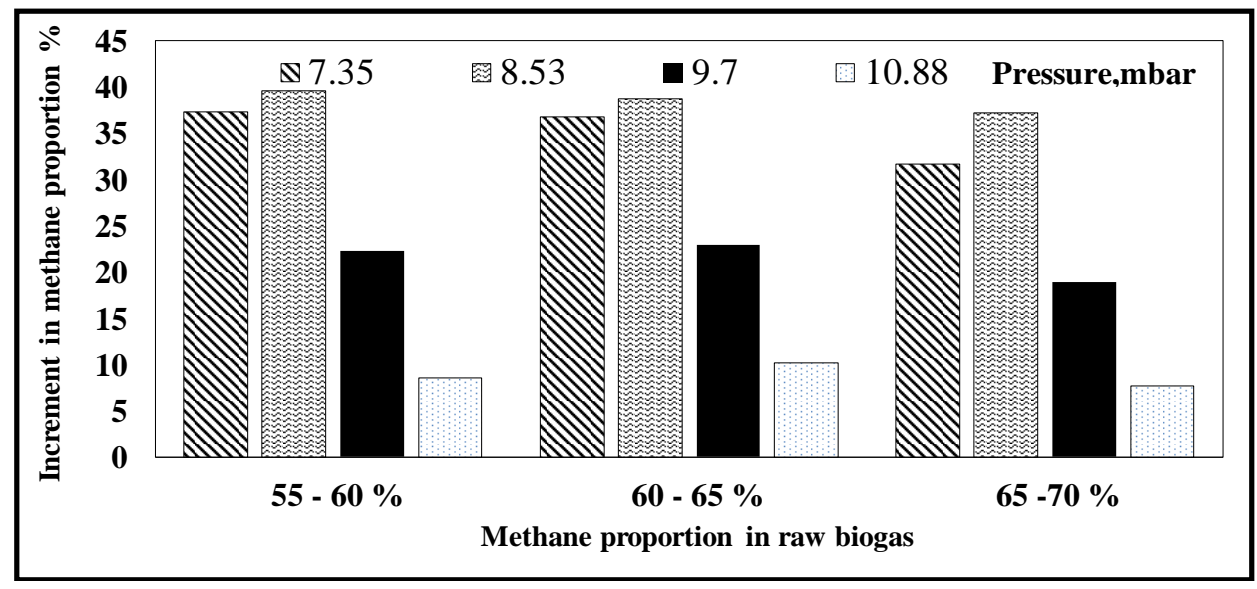

Fig. 5: Methane proportion of the purified gas at different pressures.

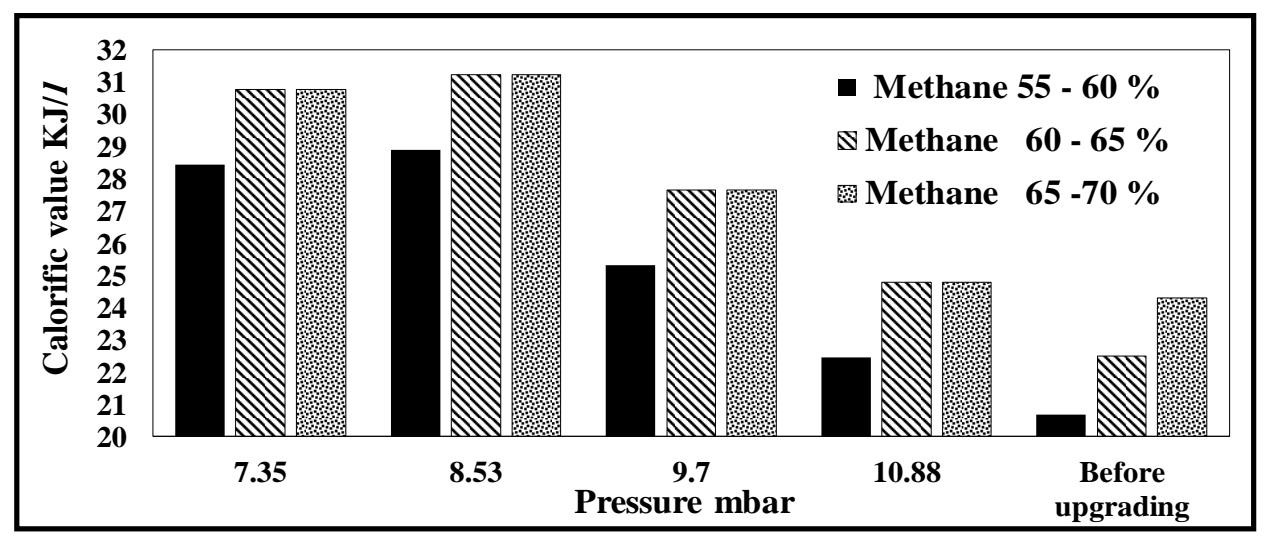

Fig. 6: Effect of pressure on calorific value of purified biogas. 
The obtained data show that increasing the gas pressure from 7.35 mbar to 8.53 mbar resulted in measured methane proportions in the raw biogas of approximately $57.5 \%, 62.5 \%$, and $67.5 \%$; the methane proportion after the upgrading process increased from $37.39 \%$ to $39.62 \%$, from $36.75 \%$ to $38.80 \%$, and from $31.73 \%$ to $37.23 \%$, respectively. Any further increase in the gas pressure up to 10.88 mbar decreased the increment in methane proportion from $39.62 \%$ to $8.54 \%$, from $38.80 \%$ to $10.21 \%$, and from $37.23 \%$ to $7.75 \%$. Furthermore, the calorific value of the purified biogas varied with the methane proportion of raw biogas for the same gas pressures. These results demonstrate that increasing methane proportion in raw biogas from $57.5 \%$ to $67.5 \%$ measured at different gas pressures of $7.35,8.53,9.70$, and 10.88 mbar increased the calorific value of the purified biogas from 28.44 to 32.01 , from 28.90 to 33.35 , from 25.33 to 28.90 and from 22.47 to $26.18 \mathrm{~kJ} / \mathrm{l}$, respectively. Gas pressures above or below the optimum value tended to decrease the increment in methane proportion due to the decrease in the friction rate requirement as well as do not provide of time required during the purification process. In addition to the increase in the calorific value of the purified biogas was caused by the decreased carbon dioxide proportion in the raw biogas at the same gas volume during upgrading process.

\section{CONCLUSION}

The present study involved designing and establishing an integrated geometrical system for producing, upgrading, and storing biogas. Experiments were performed to design and evaluate the performance of an industrial biogas digester and to optimize values from the daily volume of the gas yield and the actual calorific value of the produced gas for using biomethane in varied applications. The findings of our research are convincing, and the following conclusions can be drawn the highest value of methane production was $241.73 \mathrm{l} / \mathrm{kgOTS}$ and was $84.26 \%$ for biodegradability efficiency under three times agitation per day. Stirring during digestion process is important to increase the homogeneity. Moreover, stirring more than needed may have a negative impact on methane production and reactor performance; it also wastes energy. The relationship between the stirring rate and retention time was found to be negative. The biogas production in large-scale digesters can be optimized 
using mechanical agitation. The highest percentage of methane in the purified biogas after the upgrading process was $92.63 \pm 1.5 \%$. The methane percentage in the purified biogas increased by increasing the gas pressure up to 8.53 mbar. The highest calorific values of the purified biogas were 28.90, 31.23 , and $33.35 \mathrm{~kJ} / l$ at a constant gas pressure of $8.53 \mathrm{mbar}$, which were higher than the calorific values of the raw biogas which recorded 20.70, 22.50 , and $24.30 \mathrm{~kJ} / l$.

\section{REFERRENCES}

A.O. A. C. 2000. Official Methods of Analysis. Association of Official Analytical Chemist. EUA.

Bajracharya, R., A. Dhungana, N. Thapaliya and G. Hamal 2009. Purification and compression of biogas. A research experience. $\mathrm{J}$ Institute Eng., 7,1-9.

Bjornsson, L., B. Mattiasson and T. Henrysson 1997. Effects of support material on the pattern of volatile fatty acid accumulation at overload in anaerobic digestion of semi-solid waste. ApplMicrobiol Bio technol, 47, 640-644.

Brehmer, M., T. Eppinger and M., Kraume 2012. Influence of rheology on the flow pattern in stirred biogas plants. Chem. Ing. Tech., 84, 2048-2056.

Brunetti, A., Y. Sun, A. Caravella, E. Drioli and G. Barbieri 2015. Process Intensification for greenhouse gas separation from biogas: More efficient process schemes based on membrane-integrated systems. International Journal of Greenhouse Gas Control, 35, 18-29.

El-Bakhshwan, M. K., S. M. A. Abd El-Ghafar, M. F. Zayed and A. E. Shazly 2015. Effect of mechanical stirring on biogas production efficiency in large scale digesters. J. Soil Sci. and Agric. Eng., Mansoura Univ., 6, 47 - 63.

Gaikwad, V. R. and P. K. Katti 2015. Biogas Compression and Bottling: A Solution to Energy Crises. International Journal of Computer Applications (0975 - 8887).

Karim, K., R. Hoffmann, K. T. Klasson and M. H. Al-Dahhan 2005. Anaerobic digestion of animal waste: Effect of mode of mixing. Water research, 39(15), 3597-3606. 
Klaus, V. M. 1988. Engines for biogas. A Publication of the Deutsches Zentrum für Entwicklungstechnologien GATE, a Division of the Deutsche Gesellschaft für Technische Zusammenarbeit (GTZ) GmbH , Germany.

Kowalczyk, A., E. Harnisch, S. Schwede, M. Gerber and R. Span 2013. Different mixing modes for biogas plants using energy crops. Appl. Energy, 112,465-472.

Lemmer, A., N. Hans-Joachim and J. Sondermann 2013. How Efficient are Agitators in Biogas Digesters? Determination of the Efficiency of Submersible Motor Mixers and Incline Agitators by Measuring Nutrient Distribution in Full-Scale Agricultural Biogas Digesters Energies, 6, 6255-6273.

Lesteur, M., V. Bellon-Maurel, C. Gonzalez, E. Latrille, J. M. Roger, G. Junqua, and J. P. Steyer 2010. Alternative methods for determining anaerobic biodegradability: a review. Process Biochemistry, 45(4), 431-440.

Nallamothu, R. B., A. Teferra, and B. A. Rao (2013). Biogas purification, compression and bottling. Global journal of engineering, design and technology, 2(6), 34-38.

Okeke, C. E. and V. A. Ezekoye 2006. Design, construction and performance evaluation of plastic biodigester. The Pacific Jo. Sc. Tec.7, Nsukka, Nigeria.

Ray, N., M. Mohanty and R. Mohanty 2016. Biogas Compression and Storage System for Cooking Applications in Rural Households. International journal of renewable energy research. 6, 593-598.

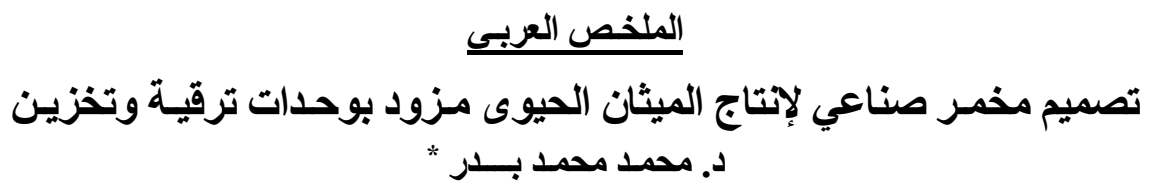

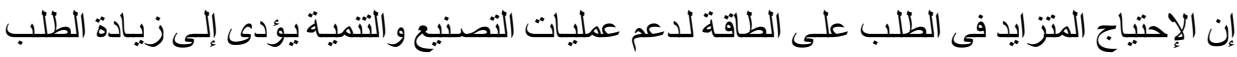

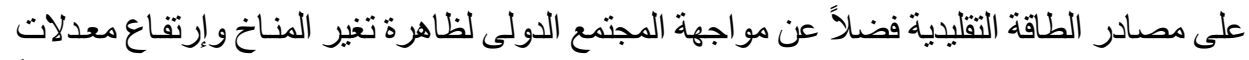

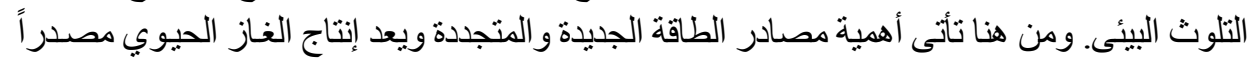

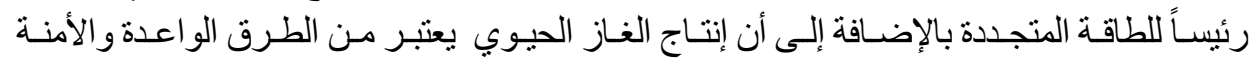
للتخلص الآمن من المخلفات الحيو النية. " قسم الهندسة الزراعية ـ كلية الزراعة - جامعة الزقازيق - مصر. 
تتاول هذا البحث تصميم وتصنيع نظام هندسي متكامل لإنتاج وتتقيـة وتخزين غاز الميثان التي يمكن

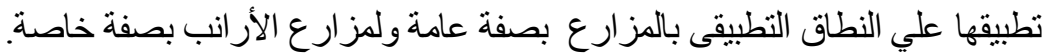
وتتمثل الأهداف الرئيسة لهذه الدر اسـة فيمـا يلي: ( ) تصميم و إنشـاء نظام هندسي متكامل لتحسين

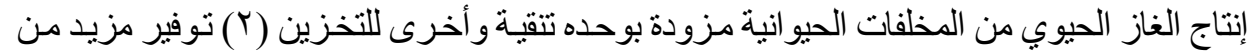

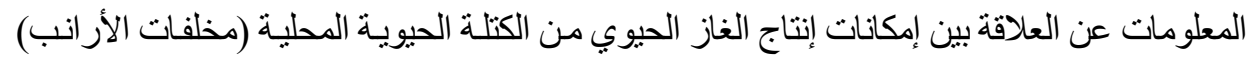

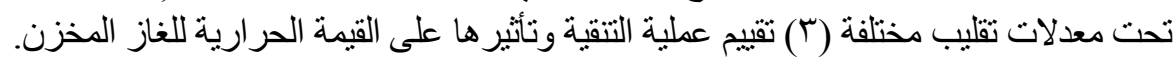

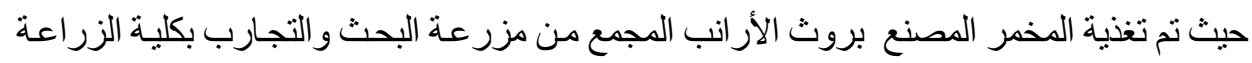

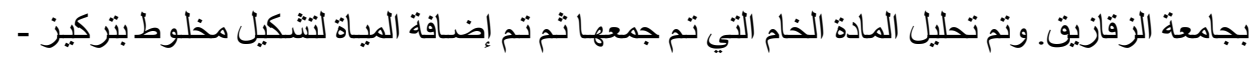

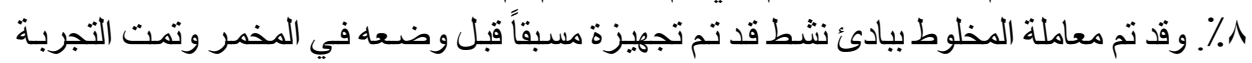

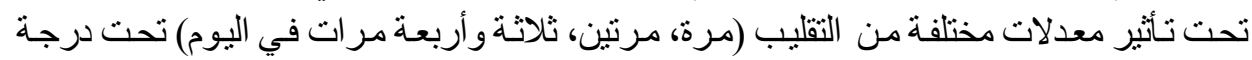
حرارة ميزوفيليك مب درجة مئوية لإنتاج الغاز الحيوي.

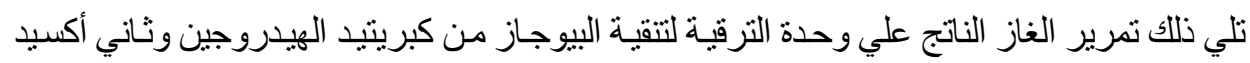

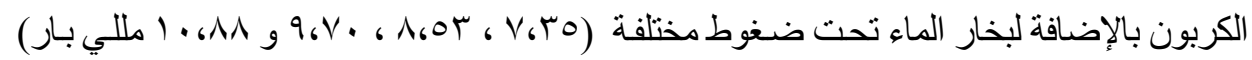

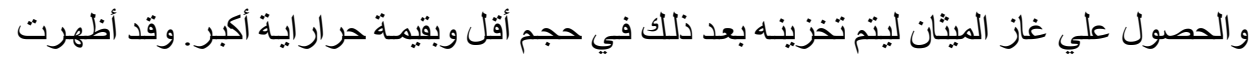

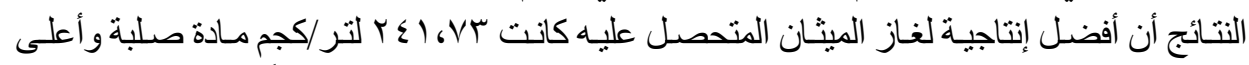

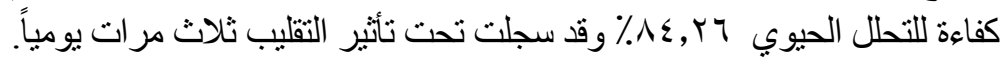
وقد لوحظ أن التقليب كان له التأثير الواضح نتيجة زيادة التجانس بين مخلفات الأرانب و المـادة النشطة

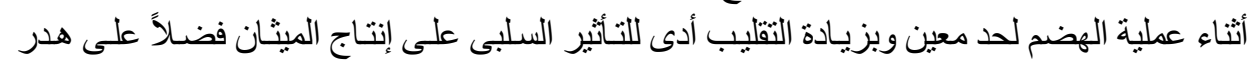

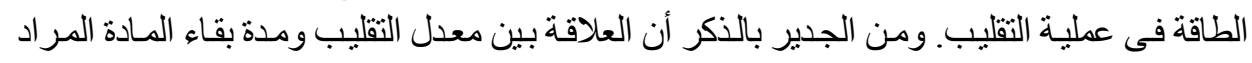

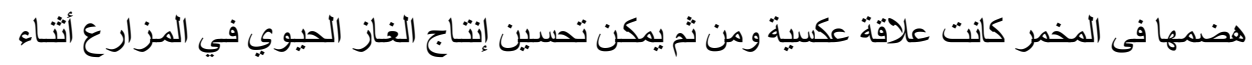
عملية الهضم على نطاق واسع باستخدام التقليب الميكانيكي.

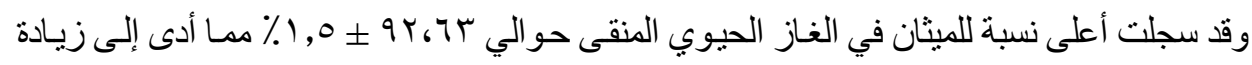

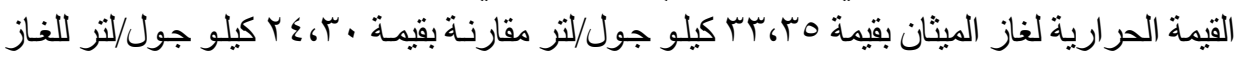
الحيوي تحت ضغط قره به، م، مللي بار بعد عملية الترقية. 